\title{
Cause and subjectivity, a comparative study of French and Italian
}

Benjamin Fagard and Liesbeth Degand

CNRS \& ENS-Paris 3 / FRS-FNRS \& UCL

\section{Introduction}

In this paper, we propose a contrastive corpus study of French car and parce que and Italian ché and perché, all four meaning (among other things) "because". Our goal is to assess the importance of subjectivity in grammaticalization in general, and in the renewal of causal conjunctions in particular. In the last thirty years, a considerable number of studies in a large array of languages have enabled linguists to better understand the way language evolves through a process known as grammaticalization. They have shown that this phenomenon, transforming lexical items into grammatical ones, and grammatical items in yet more grammatical ones, appears to work in similar ways in all languages studied to this day (B. Heine \& T. Kuteva 2002). It is now widely recognized as a major phenomenon in linguistic change (C. Marchello-Nizia 2006: 56 sqq.).

Many finer points are still open to discussion. One point in particular seems hotly debated (E. Traugott 1995, 2003, E. Traugott \& R. Dasher 2002, S. Günthner \& K. Mutz 2004, R. Waltereit 2006): the importance of subjectification and intersubjectification in the process of grammaticalization. In an earlier study, we analyzed the evolution of car and its replacement by parce que in the diachrony of French, using a measure of Speaker Involvement indicative of the degree of subjectification (H. Pander Maat \& L. Degand 2001, H. Pander Maat \& T. Sanders 2001), and found confirmation that the two phenomena can go hand in hand (L. Degand \& B. Fagard 2008): for car, there is a gradual decrease in frequency, without further grammaticalization or subjectification, whereas parce $q u e$, in the same period - from Medieval French (hereafter MedF) to Modern French (hereafter MF) -, undergoes both grammaticalization and subjectification ${ }^{\text {ii }}$.

In order to see whether this phenomenon is specific to French or more widespread, we designed a comparative study. Our goal was to observe the evolution of two causal conjunctions over a large time span, one already grammaticalized and one 'in the making', in another language. The conjunctions ché and perché, present in Medieval and Modern Italian (hereafter MedI and MI), seemed to be ideal candidates, as their history is similar to that of car and parce que: ché, like car, already exists in Late Latin (see section 1.1.3.), while perché first appears in Medieval Italian, just like parce que appears in MedF. 
In order to operationalize the study of subjectification and intersubjectification, we distinguished different types of causal relations, corresponding to the different degrees of subjectivity (or Speaker Involvement, as mentioned earlier). Causal conjunctions can be used to express objective, non-volitional causal relations, in which two states of affairs in the world are causally related (consequence-cause). They can also express more subjective, volitional causal relations, in which the deliberate action of a protagonist is explained (action-explanation). They can express subjective, epistemic causal relations, in which the opinion or claim of the speaker or of another "subject of consciousness" is justified (claim-argument). Finally, causal conjunctions can express intersubjective, interactional causal relations, where a speech-act is justified. The more a connective relates states of affairs that assume the involvement of speaker and/or hearer to build and understand the causal relation, the more it is subjective. Various superficial clues help diagnose the degree of subjectivity of a causal relation, such as the type of subject (animate $v s$. inanimate, $1^{\text {st }}$ or $2^{\text {nd }}$ person $v s .3^{\text {rd }}$ person) or the type of verb (epistemic and modal verbs, in particular, generally indicate a greater degree of subjectification). The operationalization of our hypothesis therefore implied the encoding of various morpho-syntactic clues such as verb type, tense, mode, and subject type: see our comments on examples (1) to (5), and the methodological discussions in L. Degand \& Y. Bestgen (2004) and W. Spooren \& L. Degand (In press).

In the first section of this paper, we describe the meanings and uses of these four conjunctions in Medieval and Modern French and Italian. In the second section, we present the results of a diachronic, contrastive corpus study of these conjunctions, comparing their evolution. We show that, while parce que indeed seems to have replaced car in Spoken MF, and although their evolution is quite similar, the case of ché and perché is slightly more complex.

\section{The place of ché, car, parce que and perché in the Medieval paradigms of causal conjunctions}

1.1. Origin and paradigmatical status

1.1.1. Paradigms of causal conjunctions: degree of grammaticalization

Conjunctions, at each stage of a language's evolution, display various degrees of grammaticalization. This, according to the grammaticalization theory, entails the existence of various degrees of polyfunctionality, phonetic length, syntactic freedom, and subjectivity, all of these being interrelated and amounting to the degree of grammaticalization of each item. The conjunctions of a language can therefore be distributed along a synchronic cline, schematized in Figure 1 below: 
complex, monosemic, objective

$>$ partly grammatical and polyfunctional, subjective

$>$ grammatical, polyfunctional, intersubjective

Figure 1: degree of grammaticalization and subjectivity

Placing a given conjunction at its exact spot on this cline is always a complicated task; besides, another feature of grammaticalization is that even fully grammaticalized elements retain characteristics of their earlier, more lexical uses. Indeed, although the cline in Figure 1 is synchronic, it is also a reflection of the language's evolution: when created, a new conjunction generally appears as a complex and loose structure (e.g. MF $d u$ fait que, which alternates for instance with de ce fait que) and only later, gradually, grammaticalizes ${ }^{\text {iii }}$.

In the language- and period-specific descriptions below, we will endeavour to give an account first of the array of possibilities available to speakers (of respectively MedF, MedI, MF and MI) when they want to express causality using a subordinating conjunction. This will enable us to describe more clearly the status and specificity of each element under study.

\subsubsection{Paradigm and semantics}

The causal conjunctions of Romance languages (among others) comprise morphemes which specifically and exclusively express causal relations, as well as morphemes which were originally used to express various types of semantic relations (mostly, but not only, temporal) and came to be used as causal conjunctions (see B. Heine \& T. Kuteva 2002: 328, B. Fagard 2009, A. Bertin 1997).

In our description, we will take into account the degree of grammaticalization of each item - from completely grammaticalized items to barely grammaticalized ones - as well as their degree of subjectivity and their semantics, distinguishing items with only causal uses from items which have only marginally causal uses.

\subsubsection{Etymology}

The conjunctions we chose to study all have different origins: a relative pronoun (ché), an interrogative (car), a complex prepositional construction (parce que), and finally the prepositional strengthening of a conjunction (perché). Two were formed during Late Latin and the two others during the Medieval period.

On the one hand, Italian ché and French car both originate, it seems, from Late Latin creations. According to J. Herman (1963: 143), quod was replaced by que, probably formed on a relative pronoun ${ }^{\text {iv }}$; this que is still attested as a conjunction with i.a. causal uses in most Romance languages - for instance Spanish and Portuguese que, or Italian ché. According to M. Leumann, J. Hofmann \& A. 
Szantyr (1965: II.2.2, 540 sqq.) the interrogative qua $r \bar{e}$ 'for what reason?' first appeared in the 2nd century A.D., and was later used as a relative pronoun; it survives in Gallo-Romance, namely in French car. A variety of elements usually taken to indicate the degree of grammaticalization (phonetic compactness, semantic bleaching, morpho-syntactic uses as general complementizers) show that both ché and car were already fully grammaticalized in the first MedF and MedI texts.

On the other hand, Italian perché and French parce que only appeared much later, in MedF and MedI. At that stage, they were little grammaticalized constructions with low frequency, high morpho-syntactic variability, and less semantic bleaching than ché and car. They became more grammaticalized over the centuries, and are now - in MI and MF - fully grammaticalized elements of the causal conjunctions paradigm. They actually appear to be the default causal conjunctions of Modern French (A. Nazarenko 2000: 52) and Italian (M. Rombi \& G. Policarpi 1985: 236-237, M. Samardžić 1998: 235).

\subsection{Medieval Italian}

\subsubsection{Causal conjunctions}

The most grammaticalized conjunction of MedI ${ }^{\mathrm{v}}$ used with causal meanings is ché. However, it is described by various grammars as being used 'in the stead of others' (C. Vanzon 1834: 369), showing that its use as a causal conjunction is not prototypical. There are also a variety of less grammaticalized conjunctions, such as perché, which alternates with less compact variants such as perciocché, imperciocchè, perocchè, imperocchè, imperché. All of these can appear with various written forms (perché / per che / per ché...), and have many regional variants (see G. Rohlfs 1969: 178 sqq.). They have mainly causal and final uses. The conjunctions conciosia(cosa)chè, conciofosse(cosa)chè are more genrespecific.

The causal use of temporal conjunctions is also widely attested, with fully grammaticalized items such as quando, and less grammaticalized items such as poiché, dapoiché, giacché, posciachè, dacché. Finally, the causal use of come and its compound siccome is also attested.

\subsubsection{Use of ché and perché}

Ché and perché are thus only two of the many conjunctions in MedI which have causal uses. We chose these two because they are good examples of a completely grammaticalized $v s$. a partly (and recently) grammaticalized causal conjunction. In order to have a clear idea of their uses in MedI, we conducted a corpus study on a sample of 100 occurrences of each - we first retrieved all occurrences of perché 
and ché with their graphic variants from the OVI database, then eliminated all noise (mainly non-causal uses) and finally extracted randomly 100 occurrences of each conjunction. For our present purposes, we analyzed the context in which the conjunctions occur to determine whether their meaning was mainly objective, subjective or intersubjective (corresponding grossly to the content, epistemic, and speech-act domains respectively, as described by E. Sweetser 1990).

Ché has mostly subjective and intersubjective uses:

1. Subjective ché: Or dunque no è maraviglia se fiamma d'amor $m$ 'apiglia guardando lo vostro viso, ché l'amor mi'nfiamma in foco (But now it is no wonder if love's flames catch me when I look at you, because the fire of love burns in me) (Rinaldo d'Aquino, Rime, 1250, 111)

2. Intersubjective ché: Di'mi s'è ver l'abrazzare che mi fai, donna avenente, ché sì gran cosa mi pare creder no'l posso neiente (Tell me if your embrace is a true one, oh woman so pretty, for to me it seems so great that I cannot believe it) (Compagnetto da Prato, L'amor fa una donna amare, 1300, 45)

In (1), ché has a subjective reading because an opinion of the speaker (it is no wonder) is justified, and it is intersubjective in (2) because the speaker justifies his speech-act (request). Perché has mostly objective and subjective uses, along with some intersubjective uses. In (3), perché introduces an objective cause, explaining a fact of nature. In (4) perché justifies the belief of the speaker, which makes it an epistemic (subjective) use, and in (5) again, a speech-act (command) is justified, which makes it intersubjective.

3. Objective (non-volitional) perché: Ancor che calamita petra sia, l'altre petre neenti non son cusì potenti a traier perché non hano bailia. (Though a magnet is a stone, other stones cannot attract things as efficiently, because they do not have power) (Guido delle Colonne, Rime, 13th c., 5, 110, 81-84)

4. Subjective (epistemic) perché: Però più non ne dico; ma sì pensai con meco che quattro n' ha tra loro cu' $i$ ' credo ed adoro assai più coralmente, perché 'l lor convenente mi par più grazioso (...) (But I say no more; but I did think to myself that there are four among them whom I believe in and worship much more cordially, because their nature seems to me more gracious) (Brunetto Latini, Tesoretto, 1274, 222-3, 1335-41) 5. Intersubjective perché: Et non ti fidar troppo nel lor consiglio, perchè un savio disse: le femine vincono gli uomini ne' ma' consigli (And do not 
put too much faith in their counsel, for a wise man said: women overcome men in their bad counsels) (Andrea da Grosseto, ibid., III, 23, 275)

Graph 1 illustrates the predominantly subjective and intersubjective uses of ché (epistemic and interactional make up more than $70 \%$ of occurrences), whereas perché has mostly objective and subjective uses (volitional and epistemic make up almost $80 \%$ of occurrences).

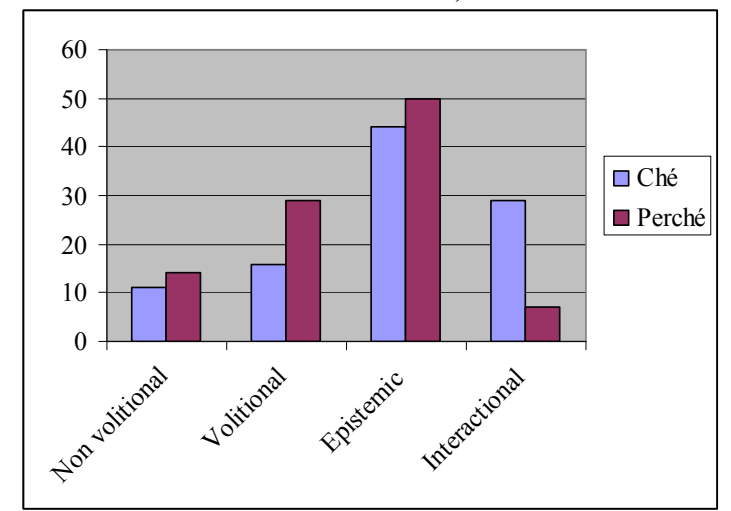

Graph 1: causal uses of ché and perché in MedI

\subsection{The paradigm of causal conjunctions in Medieval French}

\subsubsection{Causal conjunctions}

The most grammaticalized conjunctions of MedF used with causal meanings are que and car. However, the causal use of que is extremely rare, whereas that of car is very frequent. There are also a variety of less grammaticalized conjunctions with mainly causal uses, such as par/por ce que, but also little grammaticalized constructs: a cause que, vu que, a ce que, pour ce que, pour chose que, pour tant que, de ce que, moyennant que, obstant (ce) que (A. Bertin 1997).

Like in MedI, the use of temporal conjunctions is attested, with fully grammaticalized items such as quant and others like puis que/puisque. Finally, the use of $c o(m) m e$ with a causal meaning is also attested.

\subsubsection{Use of car and parce que}

Car and parce que are thus equally good examples of a completely grammaticalized $v s$. a partly (or recently) grammaticalized causal conjunction. In order to have a clear idea of their uses in MedF, we conducted a corpus study (on 100 randomly selected occurrences of each, taken from the BFM and DMF databases after removal of all non-causal occurrences). The results of this study are the following: just like ché, car has mostly subjective and intersubjective uses, 
whereas parce que has mostly objective and subjective uses, as can be seen in Graph 2 below. It should be pointed out that parce que thus seems to be less subjective yet than perché in MedI (see B. Fagard 2008).

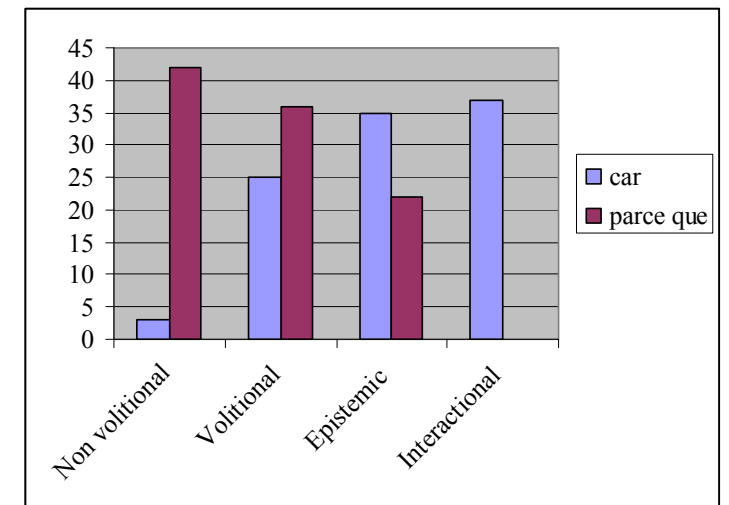

Graph 2: causal uses of car and parce que in MedF

\section{The evolution of ché, perché, car and parce que: a corpus study}

\subsection{The evolution of car and parce que from MedF to MF}

A detailed corpus study of car and parce que from MedF to MF, in various genres, enabled us to show (B. Fagard \& L. Degand 2008) that the grammaticalization of parce que was accompanied by a process of subjectification and that it ended up replacing car in the spoken language, but has not yet done so in Written French.

\subsubsection{The evolution of car}

In MedF, only car has subjective (6) and intersubjective (7) uses, but it also has objective (8) uses:

6. Subjective car: Forment m'en poise, quar mout l'avoie amé; Mes par mon chief ja sera comparé. (I am very sad, because I loved him dearly; But, I swear, he will yet be avenged) (Aliscans, 12th c.)

7. Intersubjective car: Ferez i, Francs, kar trés ben les veintrum! (Strike, Franks, for we will overcome them easily!) (Roland, c. 1100)

8. Objective car: Reposent sei quar lassét sunt. (They rest, because they are tired) (Saint Brendan, 12th c.)

The main evolution we observed is the drop in its intersubjective uses, as can be seen in Graph 3 below: 


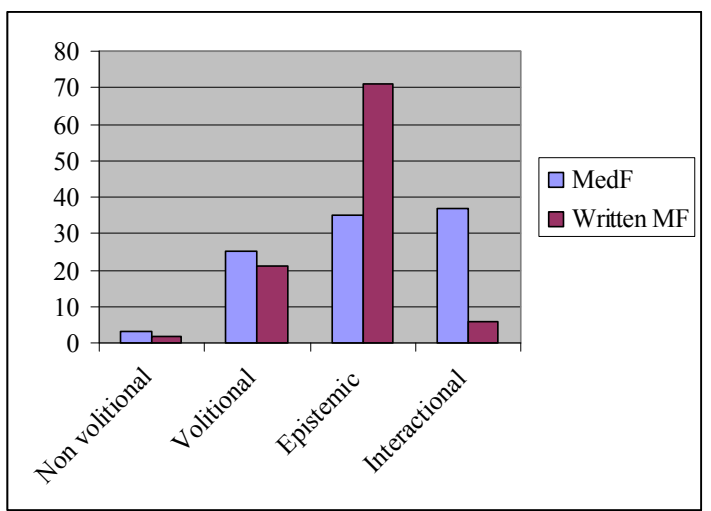

Graph 3: the meaning of causal car in MedF and Written MF

The loss of its intersubjective uses could be explained by the fact that car disappeared from standard use - it gradually loses in frequency, as can be seen in Table 1 below:

\begin{tabular}{|c|c|c|c|c|c|c|c|c|c|c|c|}
\hline Time period & $\begin{array}{l}\text { Classical } \\
\text { Latin }\end{array}$ & $\begin{array}{l}1001- \\
1329\end{array}$ & $\begin{array}{l}1330- \\
1400\end{array}$ & $\begin{array}{l}1401- \\
1500\end{array}$ & $1501-$ & $1601-$ & $1701-$ \\
1700 & 1800 & $1801-$ & $1901-$ & $\begin{array}{c}\text { 2000- } \\
19000\end{array}$ & $\begin{array}{c}2000- \\
\text { (Journalistic) }\end{array}$ & (Spoken) \\
\hline $\begin{array}{c}\text { Frequency } \\
\text { per 10 000 } \\
\text { words }\end{array}$ & 1,74 & 40,0 & 41,9 & 30,0 & 25,7 & 13,7 & 6,0 & 7,4 & 5,4 & 4 & 0,2 \\
\hline
\end{tabular}

Table 1: evolution of the frequency of Latin quare and its French outcome car (based on Table 3 in B. Fagard \& L. Degand 2008)

Its use in Spoken MF is very rare, to the point that car might be considered extinct except in formal speech, which is much closer to literary French than to the actual, everyday use of the language.

\subsubsection{The evolution of parce que}

Contrary to car, parce que seems to have had mostly objective uses (9) in MedF, but it gradually takes on more subjective uses (10), and intersubjective uses (11) appear only in Spoken MF, where parce que could be said to have replaced car.

9. Objective parce que: Li anfes ploroit de grant fin por ce que n'avoit que mengier (The child cried of hunger, because he had nothing to eat) (Roman de Renart, early 13th c.) 
10. Subjective parce que: mort me fis en mi la voie por ce que trop grant fain avoie (I played dead in the middle of the road, because I was terribly hungry) (id.)

11. Intersubjective parce que: je crois que ça s'appelle en français mais excusez-moi parce que je vais peut-être [...] estropier le mot hein / un goupillon là (I think in French it's called but never mind because I might [...] distort the word huh / a sprinkler y'know) (Valibel)

Its evolution is thus from purely objective causal uses to subjective and intersubjective uses in MF. At this stage, it still has objective ("factual" according to A. Nazarenko 2000: 61) uses, as can be seen in Graph 4 below:

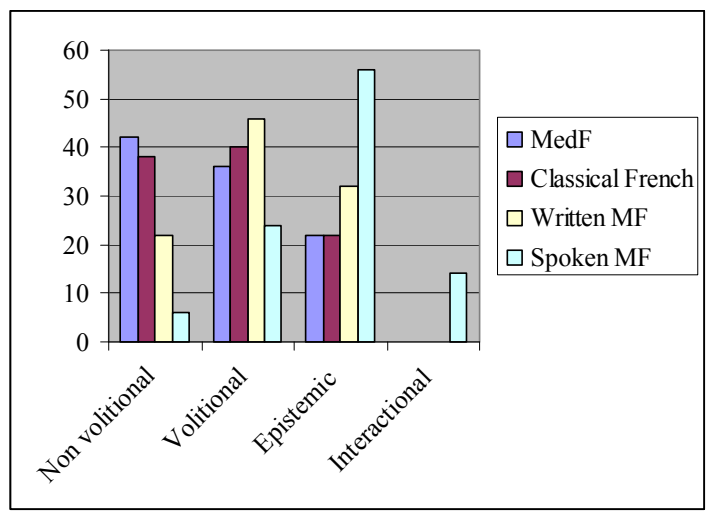

Graph 4: uses of parce que in diachrony

This evolution apparently goes hand in hand with a global increase in frequency, from 7 occurrences per ten thousand words in our MedF corpus to 37 in Spoken MF (B. Fagard \& L. Degand 2008). From the point of view of the paradigm of causal conjunctions, the evolution of car and parce que can therefore be described as follows:

- car, already completely grammaticalized in MedF, tends to decrease in frequency and becomes obsolete (at least in Spoken MF; a good indication of this is its loss of syntactic flexibility, see A. Nazarenko 2000: 72, 78)

- parce que, which only appears in Late MedF, gradually becomes more grammaticalized and subjective, finally replacing car in MF as the default causal conjunction.

This last point can be put in relation with its use as a simple (rather than complex) morpheme, in written (paske) as well as spoken language (paske, parske, parce see J. Moeschler 1986: 158, ex. 13), as in example 12: 
12. Rapido paske (< par ce que) chuis a moitié bourré ([Let's do it] fast, because I'm half drunk) (internet)

2.2. The evolution of ché and perché: a hypothesis.

Given what we know about the evolution of car and parce que, about the uses of ché and perché in MedI, and our assumptions about grammaticalization and subjectification described in section 1.1.1. above, we formulate the following hypothesis on the evolution of ché and perché:

- The more grammaticalized variant, ché, should gradually decrease in frequency and become obsolete, without necessarily changing its semantic behaviour - namely its degree of (inter)subjectivity.

- The less grammaticalized and less subjective variant, perché, should gradually gain in frequency and become more (inter)subjective.

We devised a diachronic corpus study in order to check the validity of this hypothesis.

2.3. The evolution of ché and perché: corpus study.

\subsubsection{Corpus design}

In order to analyze the evolution of ché and perché, we used a series of synchronic corpora: using various databases (mainly OVI, Repubblica and Badip), we compiled a corpus containing literary MedI, journalistic Written MI and Spoken MI. For each subcorpus, we selected all occurrences of causal ché and perché and randomly extracted 100 occurrences of each, except for ché in Spoken MI (because we found very few occurrences of causal ché, vs. more than three thousand occurrences of causal, final and/or interrogative perché $)^{\mathrm{vi}}$.

\subsubsection{Results}

The evolution of ché seems quite parallel to that of car, with little semantic evolution and almost no occurrences in Spoken MI, as we hypothesized (Graph 5). The persistence of intersubjective uses in Written MI, though, was not predicted, and could be linked to the fact that speakers spontaneously consider ché to be an abbreviation of perché, and might use it as such - something which is obviously impossible for French car and parce que. 


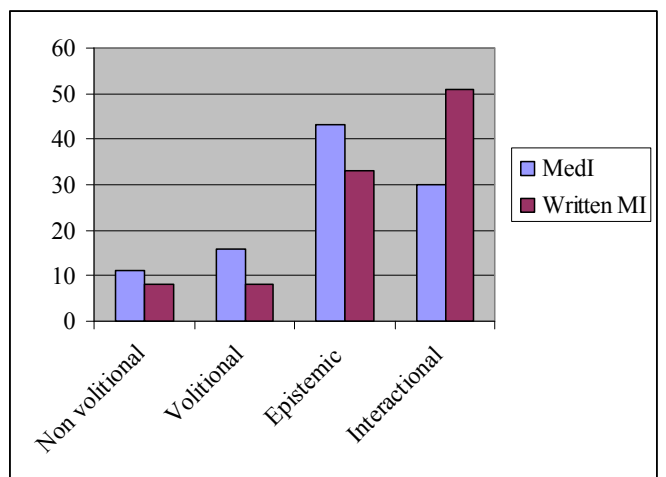

Graph 5: the meaning of causal ché in MedI and written MI

The few occurrences we found of Spoken MI ché seem to be exclusively subjective or intersubjective, as in examples 13-14 below:

13. Intersubjective ché in Spoken MI: si' leggilo leggilo tu ché io mi devo mettere gli altri occhiali (Yeah read it read it yourself because I have to put on other glasses) (Badip, R C $521 \mathrm{~A}$ )

14. Subjective ché in Spoken MI: rientro subito ché devo prendere il camioncino (I'm going home right now because I have to take the van) (Badip, M B 704 B)

The evolution of perché shows both an increase in intersubjective uses and a decrease in objective uses, from MedI to Written and Spoken MI. Perché, though it still has little intersubjective uses even in Spoken MI, thus displays the same tendency as parce que.

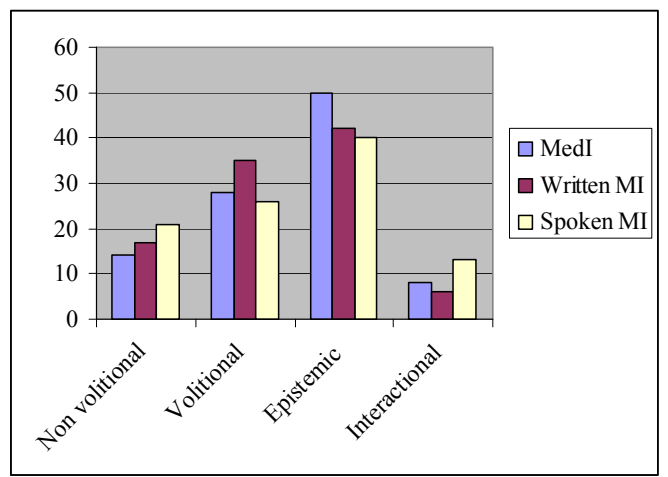

Graph 6: the meaning of causal perché in MedI, Written MI and Spoken MI

\subsection{Discussion}


Just like parce que is replacing car in MF, perché seems to be in the process of replacing ché, which appears to be in the process of disappearing from Spoken MI. This phenomenon, however, is complicated by the appearance of another che, typical of Spoken MI (M. Mancini 1994: 72, M. Berretta 1994: 254, C. Marazzini 1993: 53), which among other uses introduces a new cause (L. Renzi \& G. Salvi 1991, II: 742 sqq.). This che, it seems, is quite different from the ché studied in this paper (L. Previtera 1996): it appears not to be the direct outcome of the Late Latin general relative conjunction *que $(m)$, but to result from the causal use of the general ModI complementizer, che "that". The fact that the more grammaticalized conjunction regularly disappears is thus confirmed: it is what happened to Latin ut, later to MedF que, to MF car and MI ché. But there seem to be various replacement methods: one is the grammaticalization of a new structure, like Latin $q u \bar{a}$ re, MedF par/por ce que, MedI perché; another is the causal use of a polyvalent conjunction, like Latin quod and MI che.

\section{Conclusion}

The evolution of car and parce que in the history of French and that of che and perché in the history of Italian are, as we expected, quite similar. We predicted, on the basis of our knowledge of the evolution of car and parce que, and of the paradigm of causal conjunctions in Medieval Italian, that che would gradually lose its causal uses, while the frequency of perché and its degree of (inter)subjectivity would gradually increase.

Our corpus study partly validated this hypothesis: we have seen that two options at least exist for the replacement of a fully grammaticalized conjunction, the grammaticalization of a new conjunction or the causal use of an existing, polyvalent conjunction. Modern Italian seems to have taken both options, using perché as well as che in replacement of ché, while in Modern French parce que clearly replaced car. What seems quite clear, however, is that this replacement invariably takes place.

Summary - Cause and subjectivity, a comparative study of French and Italian

In this paper, we propose a contrastive corpus study of French car and parce $q u e$ and Italian ché and perché, meaning "because". Our goal is to assess the importance of subjectivity in grammaticalization in general, and in the renewal of causal conjunctions in particular. The evolution of these two pairs of conjunctions is quite similar: on the one hand, the most grammaticalized items of each pair, car and ché, are also the most intersubjective; they tend not to change meaning and to fall into disuse. On the other, the less grammaticalized items, parce que and 
perché, are also the less intersubjective, but gradually change meaning, possibly acquiring (more) intersubjective uses, and seem to have become the default causal conjunctions in Modern French and Italian - more clearly so in the spoken than in the formal, written varieties. There thus seems to be a link between the degree of grammaticalization and that of (inter)subjectification.

Authors' address:

Benjamin FAGARD

Lattice (CNRS - ENS)

1 rue Maurice Arnoux

92120 Montrouge

FRANCE

benjamin.fagard@ens.fr

Liesbeth DEGAND

Université catholique de Louvain

Institute for Language and Communication

Place B. Pascal, 1

1348 Louvain-la-Neuve

BELGIUM

liesbeth.degand@uclouvain.be

The authors would like to thank the anonymous reviewers for their helpful comments, as well as Paola Pietrandrea and Fabio Zinelli for their advice. This research was partly supported by the IUAP-grant P6/44 "Grammaticalization and (Inter)Subjectification" financed by the Belgian Federal Government.

\section{References}

Bentolila, F. 1986. Car en français écrit. La linguistique, 22, 95-115.

Berretta, M. 1994. Il parlato italiano contemporaneo. In Storia della lingua italiana II: Scritto e parlato, L. Serianni; P. Trifone (eds.), Torino: Einaudi, 293-270.

Bertin, A. 1997. L'expression de la cause en ancien français. Genève: Droz.

Degand, L.; Y. Bestgen. 2004. Connecteurs et analyses de corpus : de l'analyse manuelle à l'analyse automatisée. In L'Unité texte, S. Porhiel; D. Klingler (eds.), Pleyben: Perspectives, 49-73.

Degand, L.; B. Fagard. 2008. Intersubjectification des connecteurs. Le cas de car et parce que. Revista de Estudos Linguísticos da Universidade do Porto 3 (1), 119-136.

Fagard, B.; L. Degand. 2008. La fortune des mots: grandeur et décadence de car. Actes de la Conférence mondiale de linguistique française, 9-12 juillet 2008. Available online: http://www.linguistiquefrancaise.org/

Fagard, B. 2008. L'analyse sur corpus ou comment renouveler la romanistique: une étude de cas. Corpus, 7, 83-114.

Fagard, B. 2009. Grammaticalisation et renouvellement: Conjonctions de cause dans les langues romanes. Revue roumaine de linguistique LIV (1-2), 21-43. 
Günthner, S.; K. Mutz. 2004. Grammaticalization vs. Pragmaticalization? The development of pragmatic markers in German and Italian. In What makes Grammaticalization? A Look from its Fringes and its Components, W. Bisang; N. Himmelnmann; B. Wiemer (eds.), Berlin/New York: Mouton de Gruyter, 77-107.

Heine, B.; T. Kuteva. 2002. World lexicon of grammaticalization. Cambridge: Cambridge University Press.

Herman, J. 1963. La formation du système roman des conjonctions de subordination, Berlin, Akademie-Verlag.

Hoffmann, S. 2005. Grammaticalization and English complex prepositions. London / New York: Routledge.

Hopper, P.; E. Traugott. 1993. Grammaticalization. Cambridge: Cambridge University Press.

Leumann, M.; J. B. Hofmann; A. Szantyr. 1965. Lateinische Grammatik II: Lateinische Syntax und Stilistik. Munich: Handbuch der Altertumswissenschaft.

Mancini, M. 1994. Oralità e scrittura nella storia dell'italiano. In Storia della lingua italiana II: Scritto e parlato, L. Serianni; P. Trifone (eds.), Torino: Einaudi.

Marazzini, C. 1993. Storia della lingua italiana. Il secondo Cinquecento e il Seicento. Bologna: Il Mulino.

Marchello-Nizia, C. 2006. Grammaticalisation et changement linguistique, Bruxelles: De Boeck.

Moeschler, J. 1986. Connecteurs pragmatiques, lois de discours et stratégies interprétatives: parce que et la justification énonciative. Cahiers de Linguistique Française, 7, 149-167.

Moeschler, J. 1987. Trois emplois de parce que en conversation. Nouvelles approches des connecteurs argumentatifs, temporels et reformulatifs. Cahiers de Linguistique Française, 8, 97-110.

Nazarenko, A. 2000. La cause et son expression en français. Paris: Ophrys.

Pander Maat, H.; L. Degand. 2001. Scaling causal relations and connectives in terms of Speaker Involvement. Cognitive Linguistics, 12/3, 211-245.

Pander Maat, H.; T. Sanders. 2001. Subjectivity in causal connectives: An empirical study of language in use. Cognitive Linguistics, 12/3, 247-273.

Previtera, L. 1996. I costrutti causali. Studi Italiani di Linguistica Teorica e Applicata, XXV, 1, 29-46.

Renzi, L.; G. Salvi. 1991. Grande grammatica italiana di consultazione II. Bologna: Il Mulino.

Rohlfs, G. 1969 [1949-54]. Grammatica Storica Della Lingua Italiana E Dei Suoi Dialetti. Torino: Einaudi.

Rombi, M.; G. Policarpi. 1985. Mutamenti sintattici nell'italiano contemporaneo: il sistema delle congiunzioni. In Linguistica storica e cambiamento linguistico, Atti SLI, 23, L. Agostiniani; P. Bellucci Maffei; M. Paoli (eds.), Roma: Bulzoni, 225-244.

Samardžić, M. 1998. I valori della congiunzione "perché” nell'italiano antico. In Sintassi storicaAtti del XXX Congresso, P. Ramat; E. Roma (eds.), Roma: Bulzoni, 235-246.

Spooren, W.; L. Degand. (In press). Coding coherence relations: reliability and validity. Corpus Linguistics and Linguistic Theory.

Sweetser, E. 1990. From etymology to pragmatics. Metaphorical and cultural aspects of semantic structure. Cambridge: Cambridge University Press.

Tekavčić, P. 1972. Grammatica storica del l'italiano II. Bologna: Il Mulino.

Traugott, E. 1995. Subjectification in grammaticalization. In Subjectivity and subjectivisation, S. Stein; S. Wright (eds.), Cambridge: Cambridge University Press, 37-54.

Traugott, E. 2003. From Subjectification to Intersubjectification. In Motives for Language Change, R. Hickey (ed.), Cambridge: Cambridge University Press, 124-139. 
Traugott, E.; R. B. Dasher 2002. Regularity in Semantic Change. Cambridge: Cambridge University Press.

Vanzon, C. 1834. Grammatica ragionata della lingua italiana. Livorno: Angeloni.

Waltereit, R. 2006. The rise of discourse particles in Italian: A specific type of language change. In Approaches to discourse particles, B. Fraser; M.-J. Hansen; K. Fischer (eds.), Amsterdam: Elzevier, 65-82.

\footnotetext{
${ }^{\mathrm{i}}$ By and large subjectification can be described as the "the mechanism whereby meanings come over time to encode or externalize the speaker/writer's perspectives and attitudes as constrained by the communicative world of the speech event, rather than by the so-called 'real-world' characteristics of the event or situation referred to" (Traugott 2003: 126). The process often goes beyond subjective meanings towards meanings concerned with the interaction between speaker and hearer.

${ }^{\text {ii }}$ For the subjective or pragmatic uses of parce que, see F. Bentolila (1986) and J. Moeschler (1987: 99).

iii There seem to be two kinds of exceptions to this rule: first, as pointed out by P. Hopper \& E. Traugott (1993), an item undergoing grammaticalization can 'stop' anywhere on the cline. Second, as S. Hoffmann (2005) showed for complex prepositions, once a grammaticalization pattern exists, new elements can be added to a paradigm, seemingly without a gradual process of grammaticalization occurring. This is the case, it seems, for such complex prepositions as by reference to, in accordance with, etc. (ibid: 153).

iv There is no consensus, however, on the origin of ché and its Romance equivalents; see for instance G. Rohlfs (1969: 178) or P. Tekavčić (1972, II: 637).

${ }^{\mathrm{v}}$ Medieval Italian is here taken narrowly as the variety spoken or rather written in Tuscany, during the $12^{\text {th }}$ and $13^{\text {th }}$ centuries. Other dialects naturally display partly different features (G. Rohlfs 1969: 64 sqq.).

vi These data do not include the (rare) causal occurrences of polyfunctional che - see (2.2).
} 